\title{
Impact of Geometrical Construction on Students' Creativity Skills for Sustainable Development
}

\author{
Jane Itohan OVIAWE ${ }^{1 *}$, P.S.O. Uddin ${ }^{2}$ \\ Department of Vocational and Technical Education \\ Ambrose Alli University, Ekpoma, Edo State, Nigeria \\ *Corresponding author: janeoviawe@aauekpoma.edu.ng; janeoviawe98@gmail.com \\ DOI: https://doi.org/10.37134/ejsmt.vol7.2.5.2020
}

Received: 06 April 2020; Accepted: 01 September 2020; Published: 15 September 2020

Cite this article (APA): OVIAWE, J. I., \& Uddin, P. S. O. (2020). Impact of geometrical construction on students' creativity skills for sustainable development. EDUCATUM Journal of Science, Mathematics and Technology, 7(2), 40-49. https://doi.org/10.37134/ejsmt.vol7.2.5.2020

\begin{abstract}
The study investigated the perception of teachers and students on the impact of geometrical construction on students' creativity skills for sustainable development in Edo State technical colleges using descriptive survey research design. The sample for comprised of 20 technical drawing teachers and 150 year II students randomly selected from the six technical colleges Edo State. A 20-item questionnaire was derived from literature reviewed was the instrument for data collection. The instrument was subjected to face validation by three experts. Cronbach Alpha method was used to establish the internal consistency of the instrument and a reliability index of 0.85 was obtained. Mean statistic was used to answer the research questions while the t-test was used to test the null hypothesis at .05 level of significance. The findings from the study indicated among others that geometrical construction enhances students' diversity thinking; there was no significant difference between the perception of technical drawing teachers and students on the impact of geometrical construction on students' creativity skills for sustainable development. Based on the findings of this study, it was recommended among others that: technical drawing teachers should utilize problem-solving instructional methods and strategies in their lessons in order to carry each student along, enhance students divergent thinking and creative skills, foster scientific and technological discoveries.
\end{abstract}

Keywords: Technical Drawing, Geometrical Construction, Creativity Skills, Sustainable Development

\section{INTRODUCTION}

Technical drawing is the most popular, skill-oriented technical subject in any technical education programme be it at the Universities, Polytechnics, Colleges of Education (Technical), technical colleges or secondary schools [1]. It covers work done by architects, engineers, interior designers and electricians, technical drafters, craftsmen and technical teacher educators and students. Technical drawing is essentially the universal and graphic language of technology used by architects, technicians, engineers, technologists, designers, craftsmen, operators, manufacturers and industrialists to communicate ideas by means of pictures, drawings, graphics and symbols. Its objectives according to [2] are:

i. to provide an understanding of the theoretical and applied concepts relating to the use of ICT to facilitate visual communication of ideas in the construction and production industries;

ii. ii. provide introduction to modern Drawing Studio practice; lay the foundation for technological development and further studies in Building and Engineering; and

iii. stimulate, develop and enhance entrepreneurship skills in the diverse areas of Drawing Studio practice. 
Technical drawing course outline according to [2] include: (i) Drawing studio practice; (ii) Geometrical construction; (iii) Development of geometrical solids; (iv) Pictorial drawing; (v) Points and lines in space; (vi) Building and engineering design and drawing; and (vii) Business opportunities in drawing studio practice. Technical drawing is offered at the technical colleges and senior secondary schools in Nigeria for three years. During this period, technical teachers are expected to expose students to practical activities towards arousing and stimulating the students' interest in technology and cultivating their attitude positively to entrepreneurship and national development in technology. But Technical drawing has been perceived by many students as a tricky, tedious and uninteresting subject. This perception has affected their interest in Technical drawing. Researchers have attributed the lack of interest to the following factors: inadequate instructional method, teachers' inability to employ appropriate instructional materials, lack of orientation and misconceptions on the relevance of Technical drawing to man. Some technical teachers even shun teaching some topics. [3] posited that the bedrock of an educational system lies on a core of devoted, knowledgeable, competent and well-trained teachers. In the course of teaching, a competent teacher who seeks to know the students' behaviour must perceive the individual student as a whole since he/she possesses affective, cognitive and psychomotor talents. Similarly, students' participation in the teaching and learning process is critical and their perception presents methodological challenges [30. The teacher can be motivated to adjust and improve the instructional methods by being knowledgeable of the way students think and perceives him/her.

Perception is the judgment made on people and situations in life. Hence students' perception of the impact of geometrical construction in technical drawing on their creativity skills can foster students' interest and improve academic performance in Technical drawing. The areas often considered by learners in judging the teachers include the teachers' knowledge of the subject matter, communication ability, the choice of appropriate instructional methods and the general classroom management skills. Thus, a teacher who the students rate high on these indices tends to enjoy the students confidence, respect and admiration; with this the students also tend to be interested in the subject taught by the teacher (in this case Technical drawing).

Technical drawing as the major mover of all other technically related subjects that forms a picture of concept of what should be drawn before actually drawing it. Most students view Technical drawing as insignificant in life. This is only but an escapee tendency when students try to avoid Technical drawing. Considering the challenges of the $21^{\text {st }}$ century which include environmental, social and economic pressures, young people are expected to be creative, innovative and enterprising [4].

Creativity is the ability of using skills and imaginations to produce something new or an object or a work of art. It is tendency to generate or recognize ideas, alternatives, or possibilities that may be useful in solving problems, communicating with others, and entertainment [5]. Creativity is not just the use of one's imagination but the use of one's imagination followed by the act of creation [6]. The capacity to perform significant and creative thinking should be harnessed in students. [7] stated that there have been recent innovations and reforms in many curricular with emphasis on the shift from knowledge of subject facts and concepts (what students know) to broadly defined competencies (what students are able to do with what they know) to ensure that grandaunts at all levels have the skills needed in the society. The Technical drawing curriculum lays emphasis on its application for the acquisition of skills and entrepreneurship.

A skill is a person's capability to control element of behaviour, thinking and feeling within specified contexts and within particular task domain [8]. Skill is the ability to do something well, usually through training or experience. Skills can be acquired through education that will inculcate into recipients the ability to discharge effective responsibilities adequately with new knowledge. This is because any task executed by skilled persons cannot be compared with those performed by unskilled persons. Skill acquisition is the ability to learn or acquire skills. It involves the development of a new skill, practice of a way of doing things usually gained through training or experience. To [9], skill acquisition is the science that underpins movement learning and execution and is more commonly termed motor learning and control. Skill acquisition in the context of this study is the ability to be trained on geometrical construction and become creative. 
[10] stated that for one to be creative, it requires the ability to look at things in novel ways and from different angles and perspectives. To [11], creativity is the 'genetic code' of education which was essentially for the new economic circumstances of the $21^{\text {st }}$ century. The challenges of the $21^{\text {st }}$ century with its diverse innovations in technology, social and economic pressures require young people to be creative, innovative and enterprising. These attributes can be acquired through the ways technical teachers impart knowledge and skills in technical drawing.

One of the units in Technical drawing that has the potential of eliciting such skills is geometrical construction. [12] asserted that in the teaching and learning of Geometry, students should learn how geometric ideas and concepts apply to a wide range of human endeavour - in art, and in daily life outside classrooms. A modern theme and approach to geometry is Geometrical construction which concentrates on the construction of angles, triangles, quadrilaterals and loci. Geometrical construction enables students to transform imagined objects, ideas and statements into diagrams thereby creating the ability of students to apply knowledge to many vocations globally. The concept of geometry is a tool that aids logical reasoning or thinking towards arriving at meaningful inference. [13] stated that the ability to make logical reasoning and deductions helps individuals in curbing individual and societal challenges which promotes nation's building. A topic like geometrical construction involves the use of drawing instruments in constructing and building up shapes thereby eliciting creative thinking from the students.

The instructional strategies or approaches utilized in teaching a topic can promote or hinder the creative potentials possessed by the students. According to [6], some ways of teaching for increasing creativity and innovation of students have to do with the application of the basic principles of teaching are: clarity and precision, alignment, intellectual load, reconstruction of ideas, explaining, engaging, enthusing, use of cooperative learning approach, use of laboratory approach, effective use of instructional materials, use of background knowledge of the students and teaching using guided discovery approach, use of lesson study approach, teaching and giving examples on real life use of technical drawing. [12] described the learning of geometry as a process of studying the conversation of graphics in space, which can enhance children's spatial ability. The author described a five-level model on how people learn geometry. These levels are a product of experience and instruction, moving from visualization analysis, abstraction, and deduction to rigor. [12] stated that the playing of puzzle is a significant method to enhance geometric spatial thinking in students.

According to the West African Examination Council (WAEC) Chief Examiner's report of May/June 2016, many students performed poorly in the question on geometrical construction and the question was the most unpopular question in terms of students who attempted the question. It has been observed that students dread geometrical construction because of inadequate practice on the topic due to lack of teaching and learning materials on the part of the teachers and students. Students exhibit non-challant attitude towards Technical drawing in general and geometric construction in particular due to the misconception that these are not necessary to man. How can technical teachers fashion the teaching of geometrical construction to enable students relate the knowledge gained to acquire the desired skills required in the $21^{\text {st }}$ century society and workplace? This is one of the goals of sustainable development.

[14] examined the potentials of creative personality in a study on refocusing Physics Education for creativity with an imperative for sustainable development and reported that creative individuals are always motivated because they see the need for novel, varied and complex stimulations, the need to communicate values and ideas and most importantly the need to solve problems. Such individual also express unusual thought and appear to be usually bright, expressing the world in an original way with insightful perceptions that can only be understood by them. Similarly, [15] stated that the key learning processes that aligned with Education for Sustainable Development (ESD) are those of collaboration and dialogue, engagement with the 'whole system'. Furthermore, [16] posited that the ability to see the interconnections between different dimensions (environmental, development, social, economic, cultural) and the complexity of systems and situations can contribute to the effective problem-solving of sustainability issues.

According to UNESCO (2017), ESD is helping the people to develop knowledge, skills, values and behaviours need for sustainable. The promotion of ESD in education is considered crucial to building a 
sustainable future and to placing young people at the centre of development. The FRN in realizing the importance and need for sustainable industrial and technological workforce established technical colleges to turn out graduates who will be employable in the world of work. [17] stated that technical colleges are designed to prepare individuals to acquire practical skills, basic scientific knowledge and attitudes required as craftsmen and technicians at sub-professional levels. Technical colleges are the principal vocational institutions in Nigeria that give full vocational training intended to prepare students for entry into various occupations as operatives or artisans and craftsmen [17]. The technical colleges are the educational institutions responsible for turning out craftsmen and technicians in various occupation. These craftsmen are expected to acquire and apply the knowledge and requisite practical skills in their vocation to either self or paid employment. Technical college graduates should acquire academic and technical skills that afford employment and sustain their longevity as productive members in today's complex work environment [17].

ESD is an approach to teaching and learning seeks to empower people of all ages to assume responsibility for creating and enjoying a sustainable future[18]. It prepares people for all walks of life to plan for, cope with, and find solutions for issues that threaten the sustainability of our planet, and encourages changes in behaviour that will create a more sustainable future [19]. [20] posited that quality teaching lies at the teacher's capacity to transform written knowledge into forms that are pedagogically powerful and yet adaptive to the students' abilities and backgrounds. Effective teaching occurs when students learn and achieve many goals and not just being able to repeat knowledge [21]. While during effective learning, student learn how to learn, students develop conceptual understanding and thinking skills, thus helping students change their intuitive, everyday ways of explaining the world around them to incorporate scientific concepts and ways of thinking into their personal frameworks. [22] asserted that students' ability to solve problems is enhanced as learning occurs. According to ESD identified five types of learning as the basis for fostering sustainable development includes: Learning to know; Learning to do; Learning t live together; Learning to be; and Learning to transform oneself and society [23].

ESD is about providing real-world learning opportunities, engaging people in the affective, cognitive and psychomotor (practical) domains, and this require a shift of current thinking, values and practices of individuals, organizations and society [16]. Several researches have been conducted on sustainable development, much need to be done on the impact on particular topics on creativity skills of secondary school or technical college students who are meant to internalize the gained knowledge and skills for future careers in technology at the tertiary institutions. This study sought to examine the perception of teacher and students on the impact of geometrical construction in technical drawing on the creativity skills of technical drawing students in Edo State technical colleges.

\section{MATERIALS AND METHODS}

The study adopted the descriptive survey research design to investigate the perception of technical drawing teachers and students on the impact of geometrical construction on the creativity skills of students in Edo State technical colleges.

The population for the study consisted of all the technical drawing teachers and students from the technical colleges in Edo State, Nigeria. The sample for comprised of 20 technical drawing teachers and 150 technical drawing year II students selected through simple randomly sampling technique by balloting.

The instrument for data collection in the study was 20-item questionnaire developed by the researcher from literature reviewed. The instrument comprised of two sections, A and B. Section A consisted of the personal information of the respondents while section B consisted of the 20-items addressing the research questions. The questionnaire was structured on a five point Likert type scale of: Strongly Agreed (SA) - 5; Agreed (A) - 4; Undecided (U) -3; Disagreed (D) -2; and Strongly Disagreed (SD) -1 .

The instrument was subjected to face validation by three experts, two from the Department of Vocational and Technical Education and one in Test and Measurement, University of Benin, Benin City 
and Ambrose Alli University, Ekpoma both in Edo State. The suggestions and corrections of the experts were used to produce the final version of the instrument used for this study.

Cronbach Alpha method was used to establish the internal consistency of the items in the instrument. The reliability index of 0.85 was obtained. The instrument was administered with the help of five research assistants. All the 170 copies of the questionnaire were duly completed and returned after two weeks. This gave a $100 \%$ return rate.

Mean statistic was used to answer the research questions while the t-test was used to test the null hypothesis at .05 level of significance. Any item with a mean value of 3.00 and above was regarded as required while any item with a mean value below 3.00 was regarded as not required. Using the t-test statistic, the null hypothesis was rejected when the t-calculated value was greater than the t-critical but retained when the calculated value is less than t-critical value of 1.96 .

\section{RESULTS AND DISCUSSION}

Research Question 1: What is the perception of technical drawing teachers and students on the impact of geometrical construction on the creativity skills of students in Edo State technical colleges for sustainable development?

Hypothesis 1: There is no significant difference in the mean responses of technical drawing teachers and students on the impact of geometric construction on the creativity skills of students in Edo State technical colleges for sustainable development.

Table 1: Mean Ratings and t-test of responses of Teachers and Students on the Impact of Geometrical Construction on the Creativity skills of students for sustainable development

\begin{tabular}{|c|c|c|c|c|c|c|c|c|c|c|}
\hline $\mathbf{S} / \mathbf{N}$ & Items & $\mathbf{X t}$ & SDt & $\mathbf{X}_{1}$ & SD $_{1}$ & $\mathbf{X}_{2}$ & $\overline{\mathbf{S D}_{2}}$ & t-cal & Rmk & \\
\hline & & & & & & & & & RQ Ho & \\
\hline 1. & $\begin{array}{l}\text { Skills employed in geometrical } \\
\text { construction do not foster } \\
\text { creative thinking. }\end{array}$ & 2.31 & .95 & 2.40 & .87 & 2.21 & 1.02 & .54 & Disagreed & $\mathrm{NS}$ \\
\hline 2. & $\begin{array}{l}\text { Geometrical construction } \\
\text { fosters learners' divergent } \\
\text { thinking. }\end{array}$ & 4.23 & .88 & 4.30 & .96 & 4.15 & .80 & 1.27 & Agreed & NS \\
\hline 3. & $\begin{array}{l}\text { Geometrical construction aids } \\
\text { Students' develop themselves } \\
\text { for assessment of creative works. }\end{array}$ & 4.53 & .76 & 4.46 & .84 & 4.60 & .69 & -.43 & Agreed & NS \\
\hline 4. & $\begin{array}{l}\text { Geometrical construction assist } \\
\text { Students' to understand social } \\
\text { change through cultural block. }\end{array}$ & 4.51 & .83 & 4.52 & .58 & 4.49 & 1.07 & .06 & Agreed & NS \\
\hline 5. & $\begin{array}{l}\text { Personal transformation is } \\
\text { attained in geometrical } \\
\text { construction. }\end{array}$ & 4.37 & .92 & 4.43 & .78 & 4.30 & 1.06 & .55 & Agreed & NS \\
\hline 6. & $\begin{array}{l}\text { Knowledge of geometrical } \\
\text { construction is mainly utilized } \\
\text { in science and technology. }\end{array}$ & 4.48 & 1.00 & 4.40 & .82 & 4.35 & 1.18 & 1.08 & Agreed & NS \\
\hline & $\begin{array}{l}\text { Geometrical construction aid } \\
\text { learners' to think rationally. }\end{array}$ & 4.32 & .98 & 4.44 & .82 & 4.20 & 1.13 & .63 & Agreed & NS \\
\hline 8. & $\begin{array}{l}\text { Knowledge of geometrical } \\
\text { construction fosters scientific } \\
\text { and technological discoveries. }\end{array}$ & 4.50 & .64 & 4.60 & .71 & 4.40 & .83 & .66 & Agreed & NS \\
\hline & $\begin{array}{l}\text { Knowledge of geometrical } \\
\text { construction hampers scientific } \\
\text { and technological discoveries. }\end{array}$ & 2.50 & .77 & 2.60 & .58 & 2.40 & .70 & .80 & Disagreed & NS \\
\hline & $\begin{array}{l}\text { Geometrical construction develops } \\
\text { and fosters students' drawing skills }\end{array}$ & $\begin{array}{l}4.42 \\
\text { s. }\end{array}$ & .92 & 4.44 & .77 & 4.40 & 1.07 & .11 & Agreed & NS \\
\hline
\end{tabular}




\begin{abstract}
Grand Mean 4.017 $\quad .865$

Note: $\mathrm{X}_{\mathrm{t}}=$ Total Mean; $\mathrm{SD}_{\mathrm{t}}=$ Standard deviation total; $\mathrm{X}_{1}=$ Mean of teachers; $\mathrm{SD}_{1}=$ Standard deviation of teachers; $\mathrm{X}_{2}$ $=$ Mean of Students; $\mathrm{SD}_{2}=$ Standard deviation of Students; $\mathrm{N}_{1}=$ Number of teachers $(20) ; \mathrm{N}_{2}=$ Number of Students (170).
\end{abstract}

Table 1 revealed that the eight out of the 10 items had their Mean values ranging from 4.23 to 4.53 , which were above the criterion mean of 3.00 indicated that all the respondents agreed that these eight items on geometrical construction have high impact on creativity skills in students of technical colleges for sustainable development. The items are 2, 3, 4, 5, 6, 7, 8, and 10. This implies that the respondents agreed that geometrical construction: enhances students' divergent thinking, helps learners develop themselves for assessment of creative works, develop personal transformation, helps students to think logically, enhances scientific and technological discoveries, improves students' drawing skills and the knowledge is mainly applied in science and technology. While the respondents disagreed with items 1 and 9 with Mean values ranging from 2.31to 2.50; this is below the criterion Mean value of 3.00. This implies that the respondents disagreed that the skills applied in geometrical construction do not enhance creative thinking and that the knowledge of geometrical construction hinders scientific and technological discoveries. The grand mean of 4.017 with standard deviation of .865 suggested that geometrical construction in technical drawing has high impact on the creativity skills of technical college students for sustainable development in Edo State.

The $\mathrm{t}$-calculated values of all the items ranged -.43 to 1.27 were lower than the $\mathrm{t}$-critical value of 1.96 at an alpha level of .05. The result therefore indicated that no significant differences exist in the mean response of the two groups of respondents. It was therefore concluded that there is no significant difference in the mean responses of teachers and students on the impact of geometric construction on the creativity skills of students for sustainable development in Edo State technical colleges, Nigeria. The hypothesis was retained.

Research Question 2: What is the perception of technical drawing teachers and students on the impact of problem-solving approaches used in geometrical construction on the creativity skills of students in Edo State technical colleges for sustainable development?

Hypothesis 2: There is no significant difference in the mean responses of technical drawing teachers and students on the impact of problem-solving approaches used in geometric construction on the creativity skills of students in Edo State technical colleges for sustainable development.

Table 2: Mean Ratings and t-test of responses of Teachers and Students on the Impact of ProblemSolving Approaches in Geometrical Construction on the Creativity skills of students for sustainable development

\begin{tabular}{|c|c|c|c|c|c|c|c|c|c|c|}
\hline \multirow[t]{2}{*}{$\mathbf{S} / \mathbf{N}$} & \multirow[t]{2}{*}{ Items } & \multirow[t]{2}{*}{$\mathbf{X t}$} & \multirow[t]{2}{*}{ SDt } & \multirow[t]{2}{*}{$\mathbf{X}_{1}$} & \multirow[t]{2}{*}{ SD $_{1}$} & \multirow[t]{2}{*}{$\mathbf{X}_{2}$} & \multirow[t]{2}{*}{$\mathbf{S D}_{2}$} & \multirow[t]{2}{*}{ t-cal } & \multicolumn{2}{|l|}{ Rmks } \\
\hline & & & & & & & & & RQ Ho & \\
\hline 1. & $\begin{array}{l}\text { Examples used in Geometric } \\
\text { construction do not require } \\
\text { creative thinking. }\end{array}$ & 2.72 & 1.06 & 2.81 & .26 & 2.63 & .58 & .03 & Disagreed & NS \\
\hline 2. & $\begin{array}{l}\text { The problems given to learners } \\
\text { in geometrical construction } \\
\text { increases students level of } \\
\text { flexibility. }\end{array}$ & 4.44 & .65 & 4.47 & .53 & 4.40 & .54 & .71 & Agreed & NS \\
\hline 3. & $\begin{array}{l}\text { Problems given to students in } \\
\text { geometrical construction improve } \\
\text { students' divergent thinking. }\end{array}$ & $e^{4.68}$ & .59 & 4.74 & .41 & 4.63 & .51 & 1.13 & Agreed & NS \\
\hline 4. & $\begin{array}{l}\text { The problems given to students' } \\
\text { in geometrical construction do } \\
\text { not encourage multiple } \\
\text { approaches. }\end{array}$ & 2.91 & .74 & 2.94 & .74 & 2.89 & .81 & .16 & Disagreed & NS \\
\hline 5. & $\begin{array}{l}\text { The type of problems given to } \\
\text { students does not enable the } \\
\text { discovering of patterns. }\end{array}$ & 2.64 & .46 & 2.72 & .45 & 2.70 & .46 & .23 & Disagreed & $\mathrm{NS}$ \\
\hline
\end{tabular}




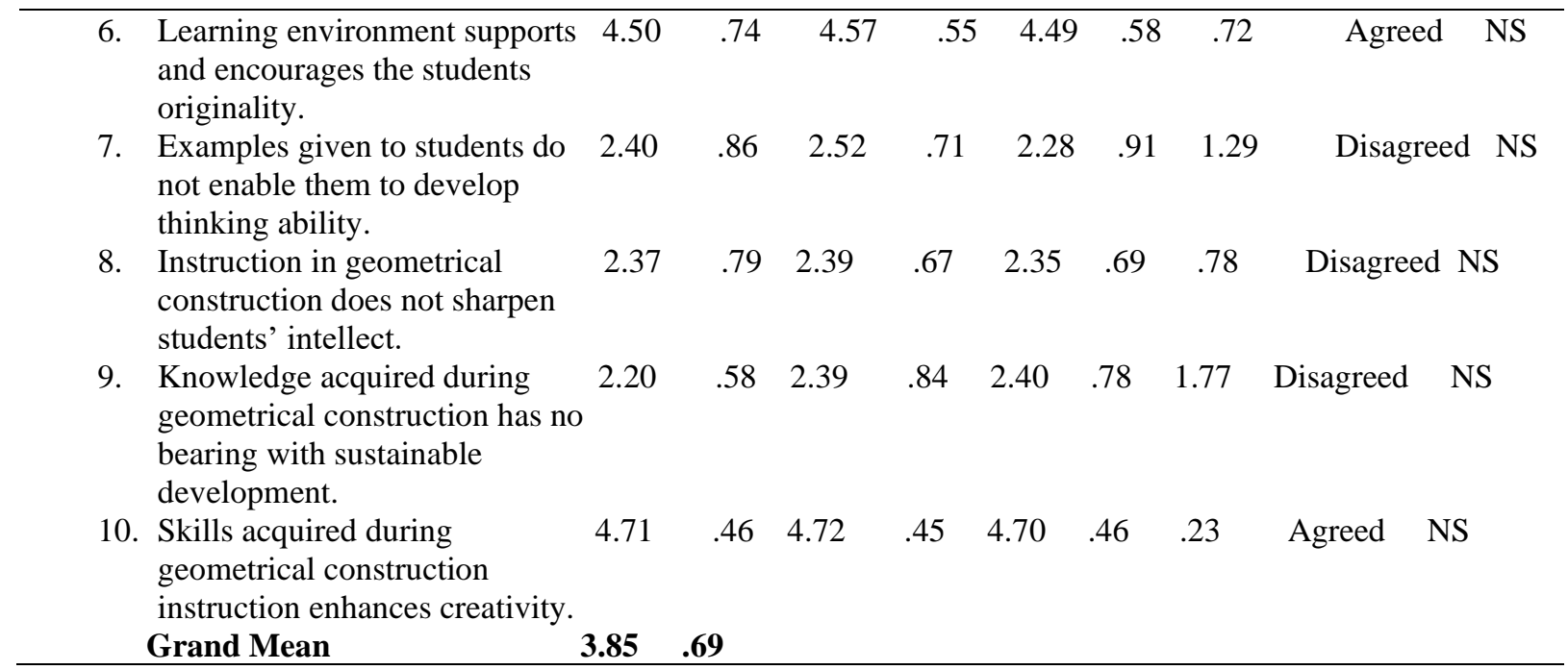

Note: $\mathrm{X}_{\mathrm{t}}=$ Total Mean; $\mathrm{SD}_{\mathrm{t}}=$ Standard deviation total; $\mathrm{X}_{1}=$ Mean of teachers; $\mathrm{SD}_{1}=$ Standard deviation of teachers; $\mathrm{X}_{2}$ = Mean of Students; $\mathrm{SD}_{2}=$ Standard deviation of Students; $\mathrm{N}_{1}=$ Number of teachers (20); $\mathrm{N}_{2}=$ Number of Students (170).

Table 2 revealed that the four out of the 10 items had their Mean values ranging from 4.44 to 4.71 , which were above the criterion mean of 3.00 indicated that all the respondents agreed that these four items on geometrical construction are problem-solving approaches used in geometric construction on the creativity skills of students of Edo State technical colleges for sustainable development. The items are 2, 3, 6 , and 10. This implies that the respondents agreed that these four items are the impact of problem-solving approaches used in geometrical construction on the creativity skills of students: the problems given to students' on geometrical construction increases their levels of flexibility, enhances students' divergent thinking, and that the learning environment supports and encourages the students' originality. While the respondents disagreed with items $1,4,5,7,8$, and 9 with Mean ratings ranging from 2.20 to 2.72 which are below the criterion Mean of 3.00. This implies that the respondents disagreed that these items on the impact of problem-solving used in geometrical construction on the creativity skills of students. These items are: examples applied in geometrical construction do not require creative thing and do not enable students to develop thinking ability; the problems given to learners do not enable the discovering of patterns and do not encourage multiple approaches; teaching and learning geometrical construction does not sharpen intellect; knowledge gained during geometrical construction has no bearing with sustainable development; and the skills gained during geometrical construction do not foster creativity. The grand mean of 3.85 with standard deviation of .69 suggested that geometrical construction in technical drawing has high impact on the creativity skills of technical students for sustainable development in Edo State.

The t-calculated values of all the items ranged .03 to 1.77 were lower than the $t$-critical value of 1.96 at an alpha level of .05. The result therefore indicated that no significant differences exist in the mean response of the two groups of respondents. It was therefore concluded that there is no significant difference in the mean responses of technical drawing teachers and students on the impact of problem-solving approaches used in geometric construction on the creativity skills of students in Edo State technical colleges for sustainable development. The null hypothesis was retained.

\section{DISCUSSION OF RESULTS}

The findings of this study in Table 1 revealed that technical drawing teachers and students perceived that geometrical construction enhances divergent thinking; aids students develop themselves for assessment of creative works. This is because geometrical construction engages the affective, cognitive and psychomotor (practical) skills of the learners thereby fostering the creativity skills in students. [6] asserted that students should always be made to understand that to live functionally in the society they have to acquire knowledge and skills to support the findings of this study. Technical drawing teachers and students perceived that geometrical construction aids students to understand social change through cultural blocks, 
personal transformation is attained in geometrical construction and knowledge of geometrical construction assists learners to think rationally. This is in line with the assertion of [24] that a person who thinks creatively can reason logically and sought through information and come up with reliable and trustworthy conclusions and ideas. The finding of this study also revealed that technical drawing teachers and students perceived that knowledge of geometrical construction fosters scientific and technological discoveries; improves students' drawing skills and knowledge is mainly applied in science and technology. [4] asserted that creative thinking is the process through which students can discover possibilities, construct objects and can act on intuition, which is higher order learning corroborated the findings of this study.

The findings of this study in Table 2 revealed that technical drawing teachers and students perceived the following as impact of problem-solving utilized in geometrical construction: the problems given to students on geometrical construction increases students' levels of flexibility; enhances students divergent thinking and that learning environment supports and encourages the students' originality. This is because proper guidance by technical drawing teachers can assist learners to be creative, self-reliant and invariably lead to sustainable development. This finding is in line with that of [4] who reported that teachers and lecturers perceived that there was readiness in students to try new ways of doing things; students could focus on a topic in logical and analytic ways for sometime, think through possible solutions, and then come up with innovative ideas. Similarly, the findings of this study is in line with that of [25] who stated that the $21^{\text {st }}$ century educational institutions has a social responsibility to equip the members of the society with necessary competencies, knowledge, understandings, and new skills so that they can constantly negotiate the changing nature of work, the labour force, information technologies and cultural identities of people. Also supporting this finding, [26] stated that creativity in teaching will require teachers who are innovative and flexible in their choice of teaching methodology and selection of situational materials.

\section{CONCLUSION AND RECOMMENDATIONS}

Based on the result of this study, all the respondents perceived that geometrical construction enhances students' divergent thinking; aids students develop themselves for assessment of creative works for sustainable development in Nigeria. Based on the findings, technical drawing teachers recommended to be exposed periodically to in-service training such as workshops, seminars and conferences. They should update their pedagogical knowledge and skills in order for them to remain current, functional and productive towards helping students to acquire the requisite $21^{\text {st }}$ century skills needed for sustainable development. Technical drawing teachers also should utilize problem-solving instructional methods and strategies in their lessons in order to carry each student along, enhance students divergent thinking and creative skills, foster scientific and technological discoveries. Moreover, the teachers should create conducive learning environment and employ adequate instructional materials to arouse and sustain students' interest and foster creativity skills.

\section{REFERENCES}

[1] Oviawe, J.I. \& Adeola, L. (2017). Effects of concept mapping instructional strategy on students' academic performance and interest in technical drawing in technical colleges in Edo State, Nigeria. IOSR Journal of Research and Method in Education (IOSR-JRME), 7(3) Ver. 1 (May-June) 9-15. Doi: 10.9790/7388-0703010915

[2] National Board for Technical Education (2008). Revised curriculum for technical colleges and polytechnics. Kaduna: NBTE.

[3] Etuk, N.E., Afangideh, M.E. \& Uya, A.O. (2013). Students' perception of teachers' characteristics and their attitude towards Mathematics in Oron education zone, Nigeria. International education studies, 6(2), 197-204.

[4] Mbanefo, M.C. (2015). Developing creativity skills in basic science students: Prospects and challenges. Journal of the science teachers association of Nigeria, 50(1), 207-216. 
[5] Franken, R.E. (2014). What is creativity? Retrieved on $2^{\text {nd }}$ January. 2015 from www.Csun.edy/vcpsyOOh/creativity/define.htm

[6] Kurumeh, M.S. \& Dogo, J. D. (2015). Teaching secondary school Mathematics for creativity and innovation for application in the transformation of the $21^{\text {st }}$ century global economy. Abacus: The journal of the Mathematical association of Nigeria, 40(1), 340-349.

[7] Gale Encyclopedia (2012). Higher education curriculum: Innovation in undergraduate curriculum Retrieved on $2^{\text {nd }}$ January. 2015 from http://www.google.com.ng

[8] Ogbuanya, T.C. \& Bakare, J. (2014). Mechatronics skills required for integration into electrical/electronic engineering technology programme in polytechnics for sustainable employment of graduates in contemporary Nigeria. Nigeria vocational association journal 19(1), 190-197.

[9] Chigbu, B.C., Onah, B.I., Ibebuif, U. \& Obi, C.A. (2017). Need for skill acquisition in data management for secondary school students' in South-East Universities for sustainable development in Nigeria. International journal of studies in education, 15(3), 35-46

[10] Bellis, M. (2014). What is creativity? How can you increase creativity? Retrieved on $2^{\text {nd }}$ January. 2015 from http://inventor.about.com/od/creativity/f/What-is-creativity.htm

[11] Grigg, R. (2010). Becoming an outstanding primary school teacher. Harlow: Pearson Educational limited.

[12] Khariree, K. (2015). Creative thinking in mathematics with Tangrams and the geometer's sketchpad. Proceedings of the $20^{\text {th }}$ Asian Technology conference in Mathematics (Leshan, China).

[13] Sambo, Y.A. (2015). Effect of teachers' background knowledge of senior secondary mathematics course contents on students' achievement in geometry. Abacus: The journal of the Mathematical association of Nigeria, 40(1), 134-142.

[14] Nwankwo, M.C. \& Okafor, T.U. (2015). Refocusing physics education for creativity: An imperative for sustainable development. Journal of the science teachers association of Nigeria, 50(1), 34-39.

[15] UNESCO (2012). Education for sustainable development action plan. Paris: France 7, place de Fontenoy. $\quad$ Retrieved $\quad$ on $\quad 5^{\text {th }}$ May, 2014 from http://unescdoc.unesco.org/images/0015/001524/152453eo.pdf

[16] Cebrian, G. \& Junyent, M. (2015). Competencies in education for sustainable development: Exploring the student teachers' views. Sustainability, 7, 2768-2786. Doi: 10.3390/su7032768

[17] Oviawe, J.I. \& Anaele, E.O. (2019). Carpentry and Joinery skills required by technical college graduates for sustainable development in Edo and Delta States, Nigeria. Being a paper presented at the $1^{\text {st }}$ International Conference and Homecoming of the Faculty of Vocational and Technical Education, University of Nigeria, Nsukka in collaboration with NKB-Lucubrate, Norway on $2^{\text {nd }}-$ $6^{\text {th }}$ July, 2019 at Princess Alexandra Auditorium.

[18] UNESCO (2005). United Nations Decade of Education for Sustainable development. Draft international implementation scheme. UNESCO: Paris, France. Retrieved on $5^{\text {th }}$ May, 2014 from http://portal.unesco.org/education/en/file_download.php/e13265d9b948898339314b001d91fd0dra ftFinal+1lS.pdf.

[19] Gisela, C. \& Merce, J. (2015). Competencies in education for sustainable development: Exploring the student teachers' views. Sustainability, 7, 2768-2786.

[20] Okafor, N.P. (2007). Re-assessing teacher education programme in Nigeria. A focus of Federal colleges of education (Technical). In: J.B. Babalola, G.O. Akpan \& A. O. Ayeni (Eds.), Managing technical and vocational education in the era of globalization, 29-32.

[21] Omoifo, C.N. (2012). Dance of the limits, reversing the trends in science education in Nigeria. Inaugural lecture University of Benin, Benin City.

[22] Omorogbe, E. \& Ewansiha, J.C. (2013). The challenge of effective science teaching in Nigerian secondary schools. Academic journal of interdisciplinary studies, 2(7), 181-188.

[23] UNESCO (2017). Education for Sustainable Development. Retrieved on 12 $2^{\text {th }}$ April, 2018 from http://en.unesco.org/themes/education-sustainable-development

[24] Bajracharya, I.K. (2010). Influencing factors of critical thinking in classroom teaching Education quarterly, 1(1), 15-21. 
[25] Rampersad, G. \& Patel, F. (2014). Creativity as a desirable graduate attribute: Implications for curriculum design and employability. Asia-Pacific journal of cooperative education, 15(1), 1-11.

[26] Fakayode, S.A. (2005). Teaching for creativity: The missing gap in curriculum implementation. In: Dada, A, Abimbade, A. \& Kolawole, O.O. (Eds.), Issues in language, communication and education. Ibadan: Constellations Books, 455-465. 